\title{
The library's Web site is the library
}

\author{
Designing for distance learners
}

by Julie Linden

A $s$ if it weren't already complicated enough to design your library's Web site for your patrons, along comes a new audience-distance learners. It is a safe bet that whether their education is delivered in limited on-campus sessions, over the Internet or through video, distance learners will increasingly look to the Web for academic support services, such as registration, course information, and the library. In fact, for distance students who seldom or never visit your library physically, the library's Web site is the library.

When designing your Web site to accommodate these students, the first and perhaps most obvious step is to acknowledge their existence. Even if your library's policy is to provicle all students with the same resources and services, some of the details will necessarily be different. Distance students don't need to know where interlibrary loan is located in the library building; they do need to know where to mail, e-mail, or fax their interlibrary loan requests.

Furthermore, unless you say so on your Web site, it is not necessarily clear to distance students whether library's resources and services are available to them. They do not want to make a phone call (possibly longdistance, possibly over several time zones) to find out whether they can use your ILL.

Even if your library does not offer a particular service or resource to distance learn- ers, say so, and, if possible, suggest an alternative. Spell it out for every resource and service included on your Web site. The following examples suggest specific information to include for various types of library resources and services; you can customize and expand upon these recommendations on your own library's Web site.

\section{Circulation}

Can distance learners borrow books from your library? For how long? Will you mail books to them or must they be checked out on campus only? Must students pay the cost of mailing them back, and what is the average cost? How are recalls handled, and what is the time period for returning recalls? If possible, provide a way for students to renew their books online (this is popular with residential borrowers, as well).

Do you have arrangements with other libraries from which your students can borrow books? What kind of identification will the student need to borrow from other libraries, and how will they obtain it?

\section{Interlibrary loan/document delivery} Can distance learners use your library's ILL, or are they expected to use their local library's ILL? Will your ILL department retrieve and send articles from your own collection? What is the turnaround time? Is document delivery (continued on page 101)

\section{About the author}

Julie Linden is research library resident at the University of Massachusetts, Amherst; e-mail: jlinden@library.umass.edu. She earned her MLS in 1998 as a distance student in Syracuse University's Independent Study Degree Program. 
workshops presented to OHR and some of our 'affiliates' were an unqualified success! I continue to hear praise for the information presented and the on-the-job usefulness of this particular workshop. . .."

Research libraries ought to consider themselves the "special library" for the university administration. Any library not pushing its client institution forward can be perceived as holding it back.

It is important, therefore, to pay attention to the administration as the "other client." Ironically, this often-ignored client is the one who pays the bills. If the administration

\section{Research libraries ought to}

consider themselves the "special

library" for the university

administration. Any library not

pushing its client institution

forward can be perceived as

holding it back.

knows how valuable the library is from its own experience, those bills are more likely to get paid.
(The library's Web site .. cont. from page 99) available to distance students? What, if anything, does it cost? Provide an online form for making ILL/document delivery requests.

\section{Reference services}

Don't make distance students phone for reference help-they probably won't. Provide e-mail service, whether you have designated one librarian or all your subject specialists to provide reference for distance learners. Let them know whether and how they can receive in-depth online consultations.

\section{Accessing online databases}

Which databases can students access remotely? Must they have an Internet account from your school or can they access the databases using any Internet service provider? Tell them how to get an account from your school and note that it may involve longdistance charges for out-of-area users. If you have a proxy server for remote access, give them instructions on how to access it. Include an e-mail address and a phone number for technical help-and expect to get at least e-mail. When you've identified a technical problem and solution, add it to the instructions or to a troubleshooting section.

If you are able to provide access to only a subset of the databases, suggest alternatives. Will you provide letters of introduction so that students can use their local college or university libraries? Will you run searches for students, and if so, what are the parameters of that service? Encourage students to e-mail you for research assistance if they cannot access your databases, as you may be able to suggest other resources that will suffice.

\section{Web site organization}

Putting all this information in one place, on a distance learners page, is efficient and will be easy to update. Remember, however, that Web users are accustomed to following different paths to reach the same information; they will not necessarily start with the distance learners page. For example, a distance learner looking for borrowing policies might start on the circulation Web page. Therefore, on the circulation page, create a "circulation for distance learners" link to the circulation section of your distance learners page.

In those instances where policies are equal or very similar for on-campus and distance students, you may wish to say so, in addition to providing a referring link. For example: "The online ILL form may be used by oncampus and distance students with a current university ID."

In creating multiple approaches to the same information, the challenges are to provide useful, but not excessive, redundancy and to avoid conflicting information. As policies change, comb the site to make sure information is updated throughout; if you have a database-driven site, you need only to update the information once in the database. The creation of a distance learners page, with links to it throughout your Web site, is the easiest way to meet these challenges.

And although you want to avoid forcing distance students to telephone you for help or information, provide phone numbers just in case they want to. 